\title{
Issues Connected to the Trade of Flowers in Romania
}

\author{
Stoian Elena, Vlad Ionela Mituko, Dinu Toma Adrian, Fintineru Gina and Temocico Georgeta \\ University of Agricultural Sciences and Veterinary Medicine of Bucharest, Romania
}

Correspondence should be addressed to: Vlad Ionela Mituko; bmitsouko@yahoo.fr

Received date: 15 April 2013; Accepted date: 10 July 2013; Published date: 11 September 2013

Academic Editor: Anca Dunarintu

Copyright (c) 2013. Stoian Elena, Vlad Ionela Mituko, Dinu Toma Adrian, Fintineru Gina and Temocico Georgeta. Distributed under Creative Commons CC-BY 3.0

\begin{abstract}
The paper has been intended to analyze trade of flowers in Romania. The study was focused on dynamics of the supplier countries for importations and destination countries for exportations. In order to design a framework for the international trade there have been assessed several indicators. Further, highlighting the trade of flowers sector, we have chosen to pay attention on the average rate of growth and links among trade figures from data series of the four main categories of flowers. This was done on destination countries and the countries suppliers for the products come from. The data has been provided by the National Statistics Institute (INS), and the Ministry of Agriculture in Romania, and has spread over a period of 10 years, starting in 2002. The results have shown that among the variables analyzed, it was detected an active trend. According to the correlation coefficients, it was stated that pairs of variables analyzed are relatively strongly correlated. The variables that have showed no significant correlation coefficients were the exchange rates for the two main currencies (Euros and the American dollars). The conclusions were that there are real connections among the considered pairs of variables, except the exchange rates which have had their own dynamics and their influence was not found on the other variables analyzed in this study.
\end{abstract}

Keywords: flower trade, Romania, average rate of growth, correlations

\section{Introduction}

In the respect of the main goals of the national economic structure for a country, the approach of international specialization explains connections between international trade and economic growth; so, the common point of these approaches is that the trade extension remains the aim of the economic development. In the following are presented several studies addressing issues related to international exchanges. Regarding the trade among countries, Houck (1988) said that "...A sizeable cross section of nations is used to provide statistical analyses of the link between agricultural productivity and economic performance, and the link between economic performance and agricultural imports...". Then, Koester (1993) stated that "...Agricultural development is more than only growth in agricultural production or productivity. However, 
it is argued that other variables which also indicate agricultural development are often closely correlated with growth in production and productivity...". In its study Winters (2004) concluded that ... "trade liberalisation induces a temporary (but possibly long-lived) increase in growth. A major component of this is an increase in productivity and argues that many of these respond positively to trade liberalisation". In the same meaning, Anantharaman (2008) was stated that "the increasing numbers of organizations involved in exporting intensifies the competition level...". In the same sense, Kuppusamy (2012) come to the conclusion that "exporting is the most common and widely used mode to enter into business at the international level. Export performance is crucial to identify the performance level of the organization ....". On national field, Lădaru and Beciu (2012) said that "...trade has a major proportion in small and medium enterprises activities, in all the Romanian areas". The European Union acts, on trade issues, as a single entity trough a common trade policy and enforced its actions with trade agreements negotiated by the European Commission, with means of the EU Treaty (TEU), establishing the aims and the objectives of EU's trade policy. (Source: Europe in figures Eurostat yearbook 2011, Eurostat). Regarding Romania, as a part of the European Union since 2007 , and „in order to meet the requirements of the Single Market it has been claimed an economic effort, as the employment of the European customs tariff assumed both advantages and disadvantages for the its economy". (Neculiţă, Şarpe, and Cristea 2011). Lastly, studies on trade are useful for the businesses which will use trade statistics to carry out research and define strategies to their partners and products. This article examines Romania's trade framework, explores the links between trade and some other variables and thus, in doing so, it offers sustained analysis and economic information on Romanian exchanges. In Romania, the share in Gross Domestic Products of trade in goods and services, recorded major differences compare to the European average. On the overall, in the last years, Romanian exports and imports for goods are about four times bigger than exports for services. The interest in transnational trade of flowers and ornamental plants allowed the appearance and development of the connected axis exporting those products where there's demand, with a whole regulation mechanism and specific indicators. For sure, there are many methodological challenges and interpretation about the strengths and the obviousness in international trade. Therefore, the necessity of this study rised from the importance of the knowledge of those factors on the exchanges outflows and the destination countries. For Romanian agricultural trade, the share of the European trade with agricultural products represents some $78.7 \%$ for imports and $72.8 \%$ for exports (2011 data) Source: Romanian Statistical Yearbooks and Ministry of Agriculture.

\section{Materials and methods}

In the present study, we have collected and processed chronological data on the international trade. This analysis consisted in calculating the average growth rate, Pearson correlation coefficients among several figures and shaping them thorough an analysis of Romania's trade with flowers. Thus, in the first part it was emphasized analysis by means of the average rate of growth; this is obtained from the average rate of dynamics and calculated as a geometric mean of dynamics index with base in chain determined for the whole series. At its turn, the dynamics index formula $\bar{I}=\sqrt[N-1]{I_{N / 1}}$ allows highlighting the link between the size and dynamics of the fixed base index for the last term of the series. Average rate of growth is a measure, noted $\bar{R}$, and can be calculated with the help of $\bar{I}$; this has the following formula: $\bar{I}=\sqrt[N-1]{\prod_{i=2}^{N} I_{i / i-1}}$, and hence, the average rate of growth is calculated using the formula : $\bar{R}=\bar{I}-1$.

The part two stresses on the correlation between pairs of variables. We have choosen data on Romanian agriculture trade, trade with flowers, monthly salary and exchange rates (U.S. Dollars and Euros rates). We may recall here that the correlation coefficient $r$, which is related to a theoretical distribution derived from time series analysis with $\mathrm{T}$ distribution. For such approach and taking into account the factors that put pressure on a phenomenon and may act differently in time, it appeals to different techniques that will express the coordinates of the analyzed developments. Thus, there were summarized and analyzed data which allowed us to calculate and interpret the correlation coefficient between different data sets. The statistical test $\mathrm{T}$ is designed and used to verify statistical assumptions, under observance of a minimum error threshold of $5 \%$. 


\section{Results and discussions}

In the first part of the paper there were analyzed seven indicators of a time series (based on average adjustments of the data series and the average rate of growth) for Romanian agricultural trade, the total volume for Romanian trade of flowers, monthly salary and exchange rates of the main currencies in the country (Euros and U.S. dollars), during 20022011

periods.

Table 1: Average rates of growth, 2002-2011 periods

\begin{tabular}{|r|l|c|c|}
\hline No. & \multicolumn{1}{|c|}{ Variables } & $\begin{array}{c}\text { Average adjustments of } \\
\text { the data series }\end{array}$ & $\begin{array}{c}\text { Rate of } \\
\text { growth }\end{array}$ \\
\hline $\mathbf{1 .}$ & Romanian food exports value & 4541,27 & $31,16 \%$ \\
\hline $\mathbf{2 .}$ & Romanian food imports value & 4374,27 & $18,84 \%$ \\
\hline $\mathbf{3 .}$ & Export of Flowers Volume & $-458,55$ & $-4,02 \%$ \\
\hline $\mathbf{4 .}$ & Import of Flowers Volume & 51995,24 & $21,26 \%$ \\
\hline $\mathbf{5 .}$ & Net Monthly Salary & 369,22 & $17,35 \%$ \\
\hline $\mathbf{6 .}$ & Euro/Lei exchange rate & 1,11 & $3,43 \%$ \\
\hline $\mathbf{7 .}$ & USD/Lei exchange rate & $-0,26$ & $-0,90 \%$ \\
\hline
\end{tabular}

†Lei - is the Romanian national currency

In the table above, we can observe that the seven datasets analyzed during the period 20022011, the volume of exported flowers and the average USD / Lei exchange rate, had negative growth rates. The other five variables had recorded important average growth rates. The largest increase was registered for the Romanian food export (31.16\%), while the lowest average growth was recorded by the
EUR/Lei exchange rate (3.43\%). The imported quantities of flowers have also recorded growing volumes $(21.26 \%)$, but the positive thing is the fact that in Romanian trade with agro-food products, exports have had a much higher growth rate (almost double) than agro-food imports (18.84\%). The graphical representation of the average rate of growth among the seven data series is done in the figure below (Fig 1).

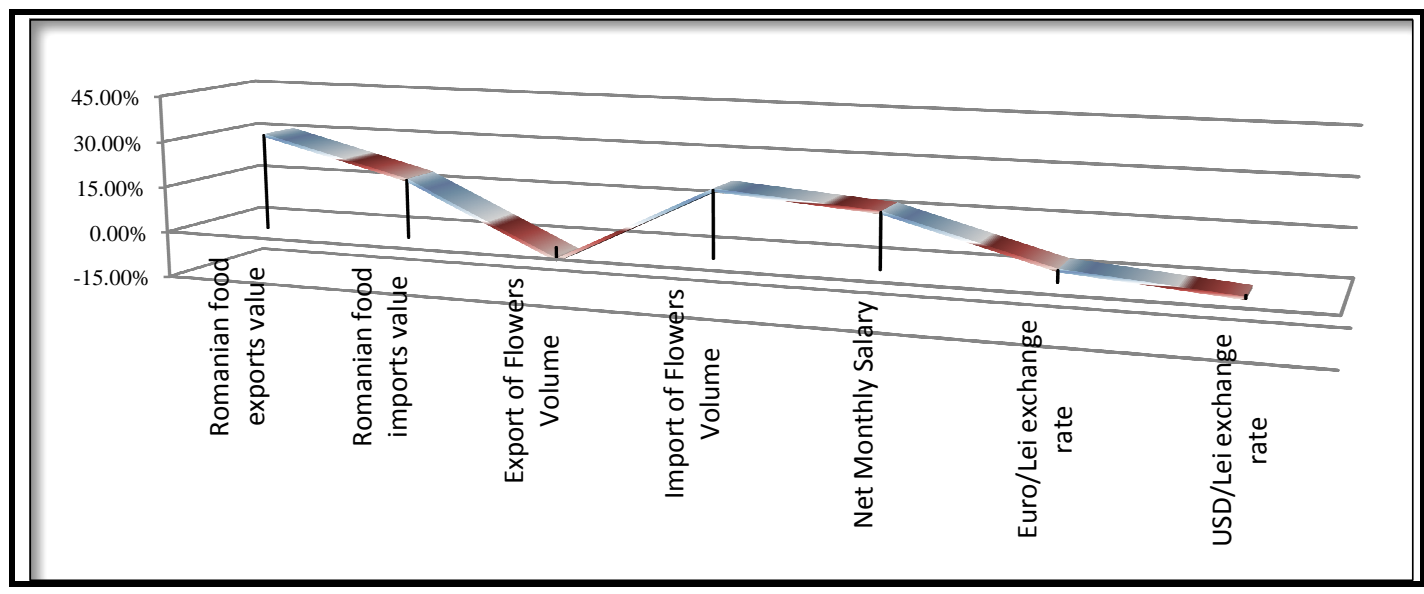

Fig. 1: Average rate of growth, 2002-2011

The items in the database of the international trade were classified according to the Commission Regulation (EC) No 1214/2007 into four categories: (1). Bulbs, tubers, tuberous roots, corms, crowns and rhizomes, dormant, in growth or in flower, (2). Other live plants 
(including their roots), cuttings and slips; mushroom spawn, (3). Cut flowers and flower buds of a kind suitable for bouquets or for ornamental purposes, fresh, dried, dyed, bleached, impregnated or otherwise prepared (4). Foliage, branches and other parts of plants, without flowers or flower buds, and grasses, mosses and lichens, being goods of a kind suitable for bouquets or for ornamental purposes, fresh, dried, dyed, bleached. Further, we have presented the destination countries for exportation and supplier countries for importation. The main countries where Romania has exported flowers are: Hungary and Germany; after the year of our country's EU accession, besides these countries, we have been count Netherlands, Italy and Austria. In the figure below are presented the top three export destination countries of Romania.

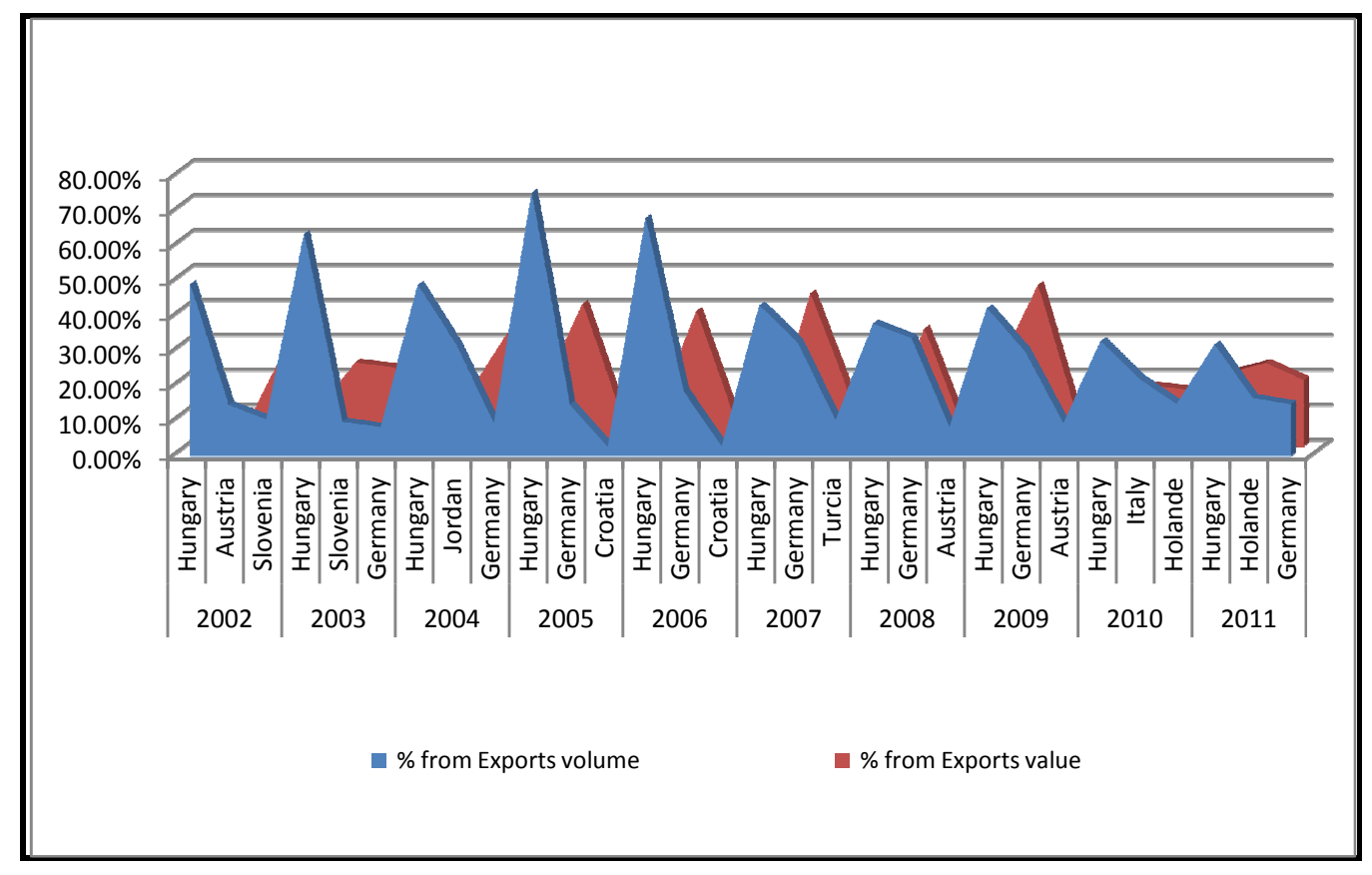

Fig. 2: The three first destinations for the trade of flowers, 2002-2011 (\%)

In the graph above there were represented on the leader-board data, exports with flowers of Romania between the countries of destination. Of these, between 2002-2011 period, Hungary stands out in terms of quantity exported flowers (a total volume of 10.536 tonnes worth \$2.406 thousands), followed by Germany (with a total volume of 2.964 tonnes, worth \$ 5.725 thousands), Austria (837 tonnes, amounting to 956 thousand \$). The dynamics of total export quantities of flowers and other categories, varied in the period 2002-2011 between 1.484 tonnes, with a total value of 742 thousand dollars (in 2002), and 1.026 tonnes, with a total value of \$ 2.882 thousand (in the year 2011).

The figures that define the total Romanian exports of flowers and other categories, in the period 2002-2011 are as follows: the total amount exported by 19.204 tonnes (the four categories existing in the database), totalling \$ 18.476 thousands. In order to analyze the importance of the different groups in terms of quantity and value, we have summarized the following figure (Fig 3). 


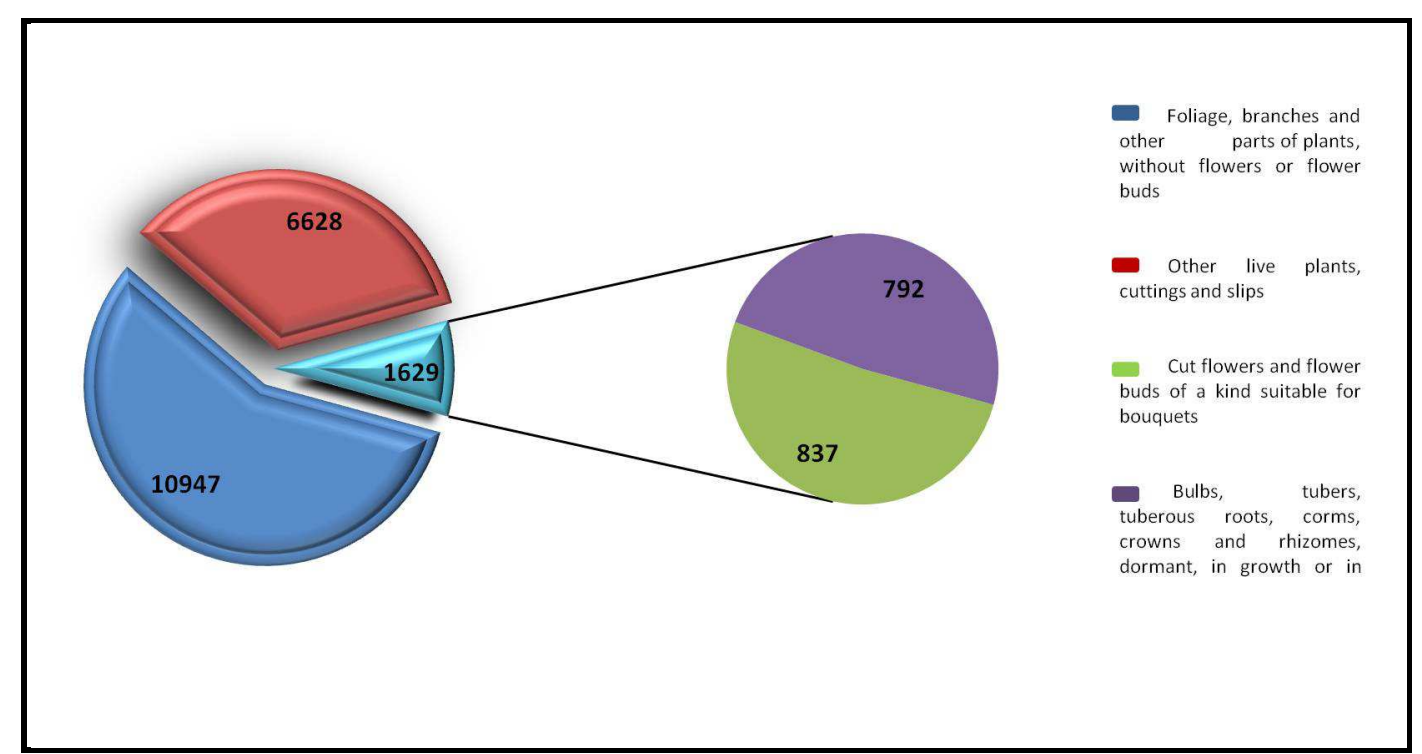

Fig. 3: Structure of exports, the most valuable categories of flowers, 2002-2011

From the above figure we find out that the most valuable category, in terms of exported quantity is "Foliage, branches and other parts of plants, without flowers or flower buds " $57 \%$ of the total quantity exported), and the least valuable in terms of amount is the category "Bulbs, tubers, corms, tuberous roots" - products which are not heavy (with $4.1 \%$ of the total quantity exported by Romania, 2002-2011 periods). Concerning the total Romania's imports of flowers, we observed that they have increased every year. During 2002-2011, the total volume imported was 11,138 tonnes (for all 4 categories), totalling in 2002 - \$11,257 thousands, up to 63,133 tonnes, totalling in 2011 - \$115,110 thousands. Countries of origin for the four imported categories listed in the Statistical nomenclature on the Common Customs Tariff (Commission Regulation (EC) No 1214/2007), are shown in the chart below (Fig 4.). During the reporting period, the data that define the total import of flowers of Romania is 370.363 tonnes, with a value of $\$ 598.194$ thousand. (Sursa: Stoian E. et al, 2013))

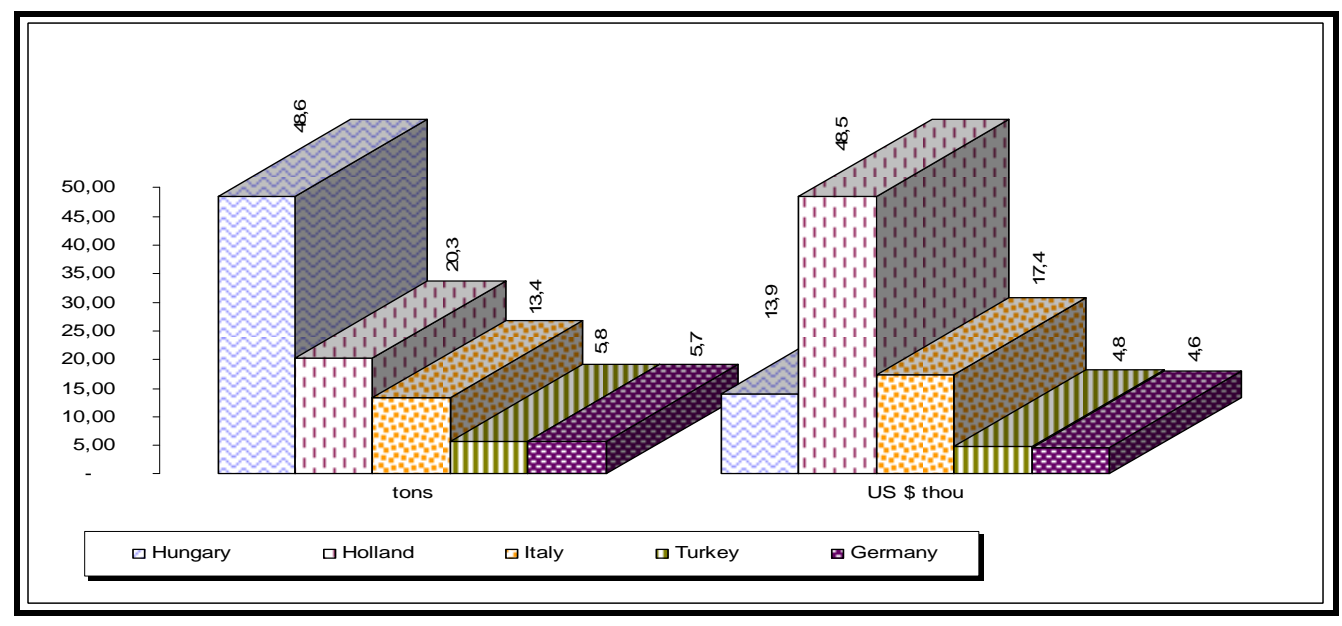

Fig. 4: Rate of Total Imports of flowers among five countries (\%), 2002-2011 
In trade analysis, we have found that it is important to make a presentation on the 4 categories existing in the structure of imports from the countries of origin. The figure that follows (Fig 5.) shows the quantities imported and their share of total imports.

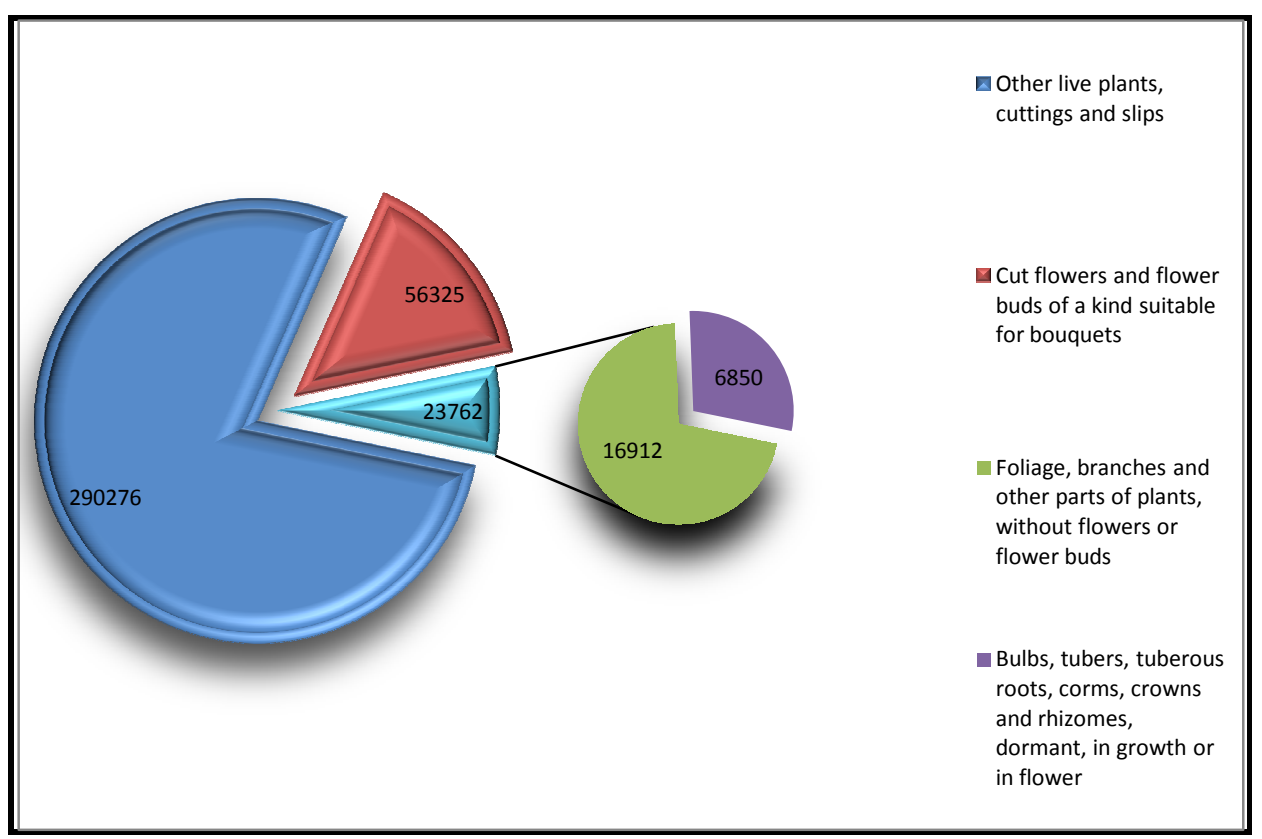

Fig. 5: Structure of imports, according to the most valuable types of flowers, 2002-2011

As it is shown in the graph above, the "Other live plants, cuttings and slips "category, occupies the highest part of total imports of flowers; the lowest share is for the "Bulbs, tubers, tuberous roots, corms, crowns and rhizomes, dormant, in growth or in flower" category with $1.8 \%$ of total. Further, in the figure below it was drawn the structure of imports, in values (Thou \$) and quantities (T), according to the four categories of flowers. (Sursa: Stoian E. et al, 2013)

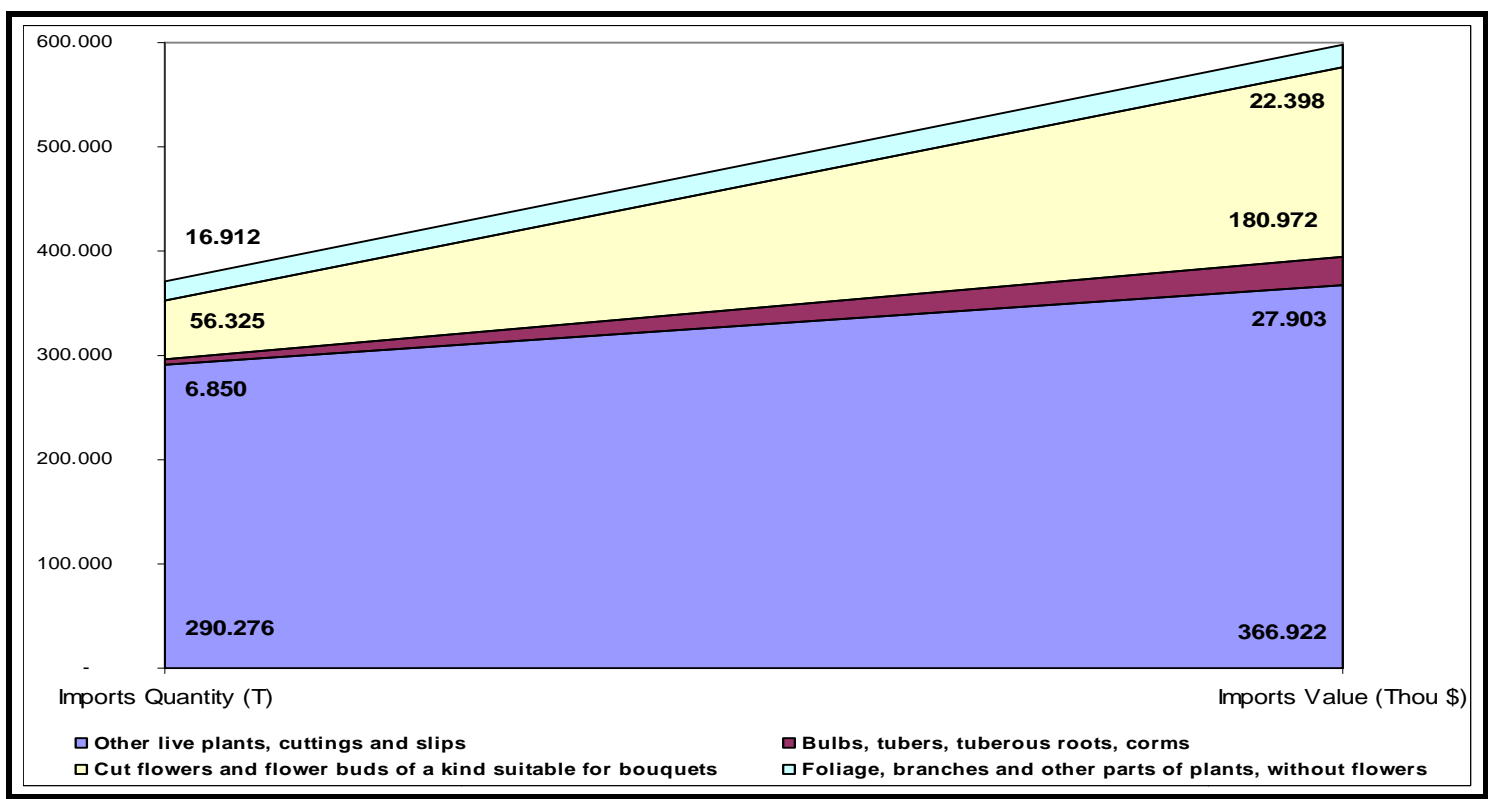

Fig. 6: The imports of the four categories of flowers spread across 4 categories 
The next figure presented the structure of imports, developed with top 3 countries. We thus find out that in the both European preaccession and post-accession period, the structure of countries from which Romania imported flowers and other categories of ornamental plants has not changed very much. Hungary remains throughout the period, the country where Romania is supplying the domestic market, followed by the Netherland Italy, Turkey and Germany. (Sursa : Stoian E. et al.,

2013)

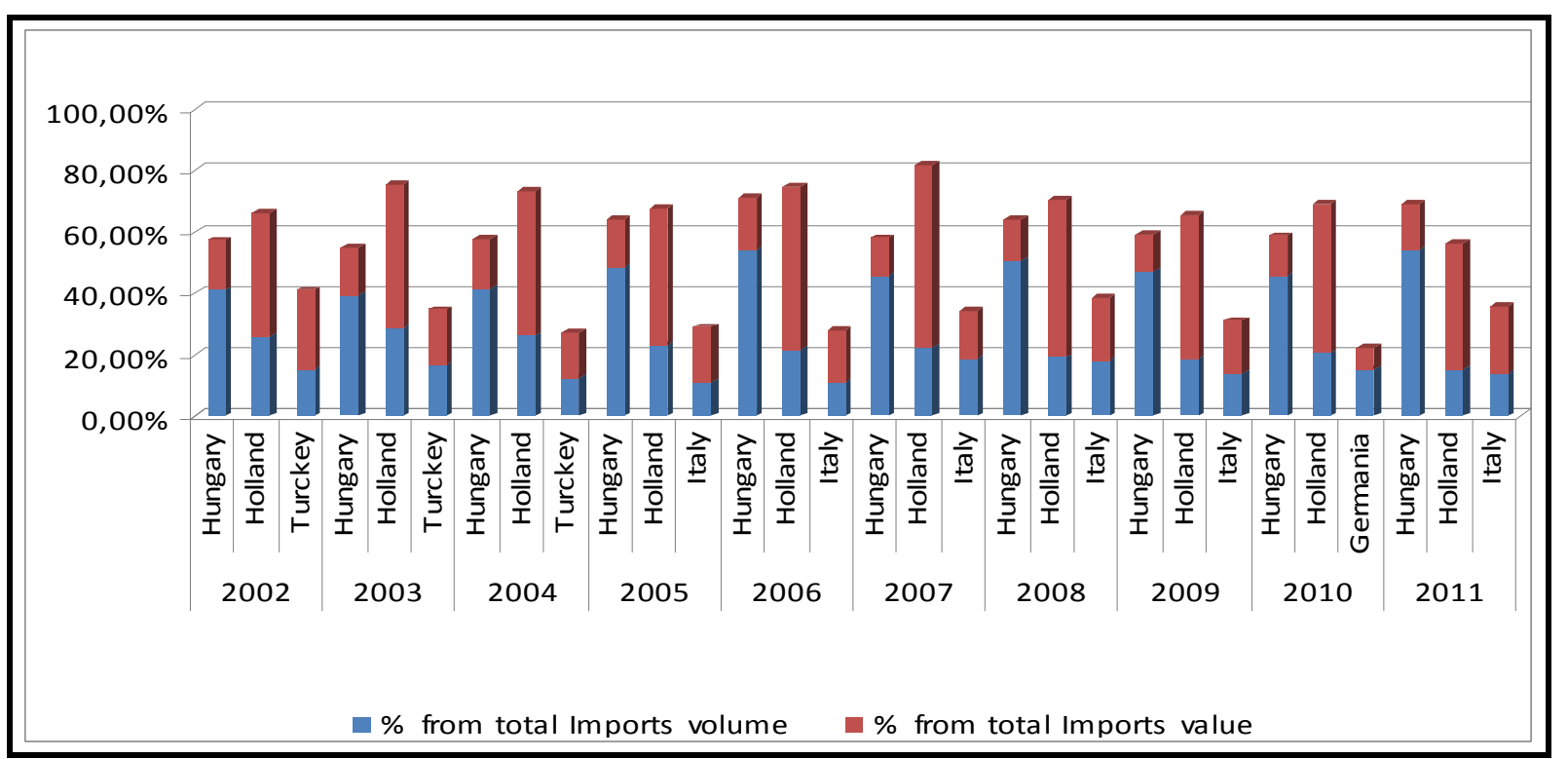

Fig. 7: The three main countries for imports of flowers and other ornamental plants, 2002-2011

In the second part of our research, we have developed correlative aspects of Romania's trade with flowers and some other variables that we considered to have an impact on trade. First of all, in what follows, we have estimated Pearson correlation coefficients between the three variables of salary (average salary, average salary in the public sector, and the average salary in the private sector), and the three main categories of exports and imports of flowers. We thus see that for exports there were achieved positive correlation coefficients (with substantial association, $r>0.5$, according to the classification of Davis) only between salary variables (net, public and private) and flowers category "Cut flowers and flower buds of a kind suitable for bouquets". In the other two cases, the correlation coefficients obtained are negative moderate association (for the category "Other live plants, cuttings and slips", r $>0.3$ ) and substantial negative association (for the "Foliage, branches and other parts of plants, without flowers or flower buds", $r>0.5$ ). Regarding the correlation coefficients of variables salary, the imports as a whole, reveals a substantial positive association between all variables, the highest being recorded for "Other live plants, cuttings and slips". In the next table are presented the results of the correlation coefficients breaking down by the main categories of flowers and ornamental plants.

Table 2: Results of the correlation coefficients between the trade and salary, 2002-2011

\begin{tabular}{|r|l|c|c|}
\hline No. & \multicolumn{1}{|c|}{ Pairs of variables } & Exports & Imports \\
\hline $\mathbf{1 .}$ & Total Net Salary - "Other live plants, cuttings and slips" & -0.47 & 0.99 \\
\hline $\mathbf{2 .}$ & $\begin{array}{l}\text { Total Net Salary - "Cut flowers and flower buds of a kind } \\
\text { suitable for bouquets" }\end{array}$ & 0.61 & 0.71 \\
\hline $\mathbf{3 .}$ & $\begin{array}{l}\text { Total Net Salary - "Foliage, branches and other parts of } \\
\text { plants, without flowers/flower buds" }\end{array}$ & -0.69 & 0.85 \\
\hline $\mathbf{4 .}$ & Public sector Salary - "Other live plants, cuttings and slips" & -0.46 & 0.98 \\
\hline
\end{tabular}




\begin{tabular}{|r|l|c|c|}
\hline No. & Pairs of variables & Exports & Imports \\
\hline $\mathbf{5 .}$ & $\begin{array}{l}\text { Public sector Salary - "Cut flowers and flower buds of a } \\
\text { kind suitable for bouquets" }\end{array}$ & 0.51 & 0.73 \\
\hline $\mathbf{6 .}$ & $\begin{array}{l}\text { Public sector Salary - "Foliage, branches and other parts of } \\
\text { plants, without flowers/flower buds" }\end{array}$ & -0.67 & 0.79 \\
\hline $\mathbf{7 .}$ & Private sector Salary - "Other live plants, cuttings and slips" & -0.47 & 0.99 \\
\hline $\mathbf{8 .}$ & $\begin{array}{l}\text { Private sector Salary - "Cut flowers and flower buds of a } \\
\text { kind suitable for bouquets" }\end{array}$ & 0.65 & 0.70 \\
\hline $\mathbf{9 .}$ & $\begin{array}{l}\text { Private sector Salary - "Foliage, branches and other parts of } \\
\text { plants, without flowers or flower buds" }\end{array}$ & -0.69 & 0.86 \\
\hline
\end{tabular}

The following table summarizes the Pearson correlation coefficients and the significance level, for 10 observations. The variables that were taken into account are: the value of imports and exports of agricultural products for
Romania, average salary, volume and values of Romanian trade of flowers and the average exchange rates for major currencies used in our country (Euros and U.S. dollars).

Table 3: Paired Samples Correlations

\begin{tabular}{|c|c|c|c|}
\hline \multicolumn{2}{|r|}{ Pair of variables } & Correlation & Sig. \\
\hline Pair 1 & $\begin{array}{l}\text { Agro-Food Exports Value \& Exchange rate } \\
\text { USD/Lei }\end{array}$ & -0.148 & 0.683 \\
\hline Pair 2 & $\begin{array}{l}\text { Flowers Export Value \& Exchange rate } \\
\text { USD/Lei }\end{array}$ & -0.128 & 0.724 \\
\hline Pair 3 & $\begin{array}{l}\text { Agro-Food Imports Value \& Exchange rate } \\
\text { USD/Lei }\end{array}$ & -0.555 & 0.096 \\
\hline Pair 4 & $\begin{array}{l}\text { Flowers Import Value \& Exchange rate } \\
\text { USD/Lei }\end{array}$ & -0.421 & 0.226 \\
\hline Pair 5 & Agro-Food Imports Value \& Total Net Salary & 0.971 & 0.000 \\
\hline Pair 6 & Flowers Import Value \& Total Net Salary & 0.990 & 0.000 \\
\hline Pair 7 & $\begin{array}{l}\text { Agro-Food Exports Value \$\& Total Net } \\
\text { Salary }\end{array}$ & 0.928 & 0.000 \\
\hline Pair 8 & Val Exp Flowers Total \& Total Net Salary & 0.692 & 0.027 \\
\hline Pair 9 & $\begin{array}{l}\text { Flowers Export Value \& Exchange rate } \\
\text { Euro/Lei }\end{array}$ & 0.577 & 0.081 \\
\hline Pair 10 & $\begin{array}{l}\text { Flowers Import Value \& Exchange rate } \\
\text { Euro/Lei }\end{array}$ & 0.556 & 0.095 \\
\hline Pair 11 & Total Net Salary \& Exchange rate Euro/Lei & 0.612 & 0.060 \\
\hline Pair 12 & $\begin{array}{l}\text { Agro-Food Imports Value \& Exchange rate } \\
\text { Euro/Lei }\end{array}$ & 0.491 & 0.150 \\
\hline Pair 13 & $\begin{array}{l}\text { Agro-Food Exports Value \& Exchange rate } \\
\text { Euro/Lei }\end{array}$ & 0.678 & 0.031 \\
\hline
\end{tabular}

†Lei - is the Romanian national currency 
In terms of analyzing correlative phenomena between pairs of variables chosen for this study (13 pairs), we have outlined the following results in the table previous. The above table has been revealed significant coefficients at a threshold of $p<0.05$ for five pairs of variables.

The two currencies have not considered any significant correlation coefficient, except for the pair the agro-food exports and exchange rate Euro. At first sight it would think that any of the considered trade variables does not affect the evolution of the Euros and U.S. Dollars currencies trend. Otherwise, we have strong significant correlations between Romania's total net salary and agro-food trade. Thus, there are only pairs $5,6,7,8$ and 13 with a significance level (less than 0.05), so the variable in the each pair are considered to have influence on each other. In this case, the salary follows the same trend as the agro-food trade and the flower trade, along the 2002-2011 periods.

\section{Conclusions}

As we have already mentioned at the beginning, the aim of this paper was to present the main aspects related to the Romanian international trade, more specifically to the trade of flowers. Thus, the findings revealed that international trade performance with flowers has a direct link with average salary and the Romanian agrofoods trade, but no connection has been identified with the exchange rates for the Euro currency and the US dollars. Concerning the average rate of growth, the conclusions were that, except the volume of flower trade and the exchange rate of the U.S. dollar, all the variables have been registered positive dynamics. The highest dynamics has been showed for the value of the agro-foods exports time series. The average rate of the dynamic for the value of the Romanian agro foods imports and the average salary, both have been situated around the $17 \%$. In the results relating to matters correlative aspects, we have shown significant correlations between variables, which mean that in the absence of any other information to support or contradict these assumptions; we can assume that these variables had a greater interdependence.

\section{References}

Anantharaman, R.N. and Kuppusamy, J. (2008), 'An analysis of competencies and moderating influence of demographic profiles - evidence from exporting organizations', Communications of the IBIMA, Volume 5.

Eurostat Yearbook 2011, (2012), 'Europe in figures', Chapter 9 "International trade", Eurostat.

Houck, J.P. (1988), 'Link between agricultural assistance and international trade', Agricultural Economics, Volume 2, Issue 2, Pages 159-166, ISSN 0169-5150, http://www.sciencedirect.com/science/article/ pii/016951508890014X.

Koester, U. (1993), 'International trade and agricultural development in developing countries: Significance of the Uruguay round of GATT negotiations', Agricultural Economics, Volume 8, Issue 4, Pages 275-294, ISSN 01695150 ,

http://www.sciencedirect.com/science/article/ pii/016951509390038E.

Kuppusamy, J. and Anantharaman, R.N. (2012), 'The link between export performance and export development: does managements' motivation play a role?', IBIMA Publishing, Journal of organizational management studies, Vol. 2012 (2012), article id 645053, 11 pages, Doi:10.5171/2012.645053,http://www.ibimapubl ishing.com/journals/joms/joms.html.

Lădaru G.R. and Beciu S., (2012) 'The SMEs sector in Romania: Comparative study by economic sector and regional level', International symposium "Sustainable agriculture and rural development in terms of the Republic of Serbia strategic goals realization within the Danube Region" - preservation of rural values, Belgrade, Serbia, pg. 1273-1288.

Neculiţă, M., Şarpe, D.A., Cristea, V., Xiaoshuan, Z. and Moga, L.M. (2011), 'Modeling the impact of Romania's accession to European Union on trade of live animals', WFL Publisher, Science and Technology.

Romanian Statistical Yearbooks, INSSE, Bucharest.

Stoian, E., Vlad, I.M., Dinu, T.A., Fintineru, G., Temocico, G. (2013), "The links and correlations in the trade of flowers in Romania", the 21st IBIMA, 27-28 June 2013", Viena

Winters, A.L. (2004), 'Trade liberalization and economic performance: an overview', The Economic Journal, 114 (February), Royal Economic Society, Published by Blackwell Publishing, Oxford, USA 